DOI:10.22337/2587-9618-2018-14-3-50-58

\title{
THE COMPARATIVE ANALYSIS OF THE RESULTS OF REAL AND NUMERICAL EXPERIMENTS FOR DEFINING THE ULTIMATE BEARING CAPACITY OF LIGHT GAUGE STEEL STUDS "ATLANT"
}

\author{
Galina G. Kashevarova, Pavel A. Kosykh \\ Perm National Research Polytechnic University, Perm, RUSSIA
}

\begin{abstract}
The article in question describes the results of comparison of numerical and real experiments, presented in the report of the Canadian laboratory "Bodycote" [1]. The paper depicts the test fixture, on witch six samples (two typical sizes) of light gauge steel stud "ATLANT" were tested. As a result, dependencies between bearing capacity and characteristic displacements were received. In order to repeat the experiment, the series of computer models were created with the software ANSYS. The computer models have complex nature: geometrical / physical nonlinearity was used. For accounting steel material nonlinearity, we used a multilinear model with isotropic hardening (MISO). The proper diagram was used for each typical size in accordance with the experiments on the tensile-testing machine. For the purpose of supporting condition and load modeling which are identical to the full-scale experiment, a couple of contact elements were used. The utilization of contact elements allowed us to consider friction between the sample and the supporting structures. One of the disadvantages of the full-scale experiment is the absence of measurements of the initial geometrical imperfections. For their consideration the use of probabilistic approach is suggested. This approach entails calculation of several models with different spread of initial imperfections. The initial geometrical imperfections with stochastic nature were included in the computing model. Parameters of distribution were based on the measurements of eighty-eight C-shaped members [8]. In the result of comparison, fine precision in terms of the ultimate bearing capacity and deformation pattern were established. According to expectation, the results of the full-scale experiments were found inside the fictitious "corridor", created in accordance with the results of computer modeling.
\end{abstract}

Keywords: light gauge steel members, "ATLANT" studs, ANSYS, initial geometrical imperfections, real experiment

\section{СРАВНИТЕЛЬНЫЙ АНАЛИЗ РЕЗУЛЬТАТОВ НАТУРНОГО И ЧИСЛЕННОГО ЭКСПЕРИМЕНТОВ ПО ОПРЕДЕЛЕНИЮ ПРЕДЕЛЬНОЙ НЕСУЩЕЙ СПОСОБНОСТИ ТОНКОСТЕННЫХ ПРОФИЛЕЙ «АТЛАНТ»}

\author{
Г.Г. Кашеварова, П.А. Косых \\ Пермский национальный исследовательский политехнический университет, г. Пермь, РОССИЯ
}

\begin{abstract}
Аннотация: В статье выполнено сравнение результатов натурных экспериментов, изложенных в отчете Канадской лаборатории Bodycote [1], с результатами компьютерного моделирования. Описан испытательный стенд, на котором было испытано шесть образцов (двух типоразмеров) тонкостенных профилей марки «АТЛАНТ». В результате были получены зависимости между сжимающей силой и характерными перемещениями. С целью повторения эксперимента в расчетном комплексе ANSYS была создана серия компьютерных моделей. Модели содержат как физически, так геометрически нелинейную постановку задачи. Для учета физической нелинейности стали использована полилинейная модель с изотропным упрочнением (MISO). Для каждого типоразмера применялась своя диаграмма, соответствующая испытаниям на разрывной машине. С целью моделирования условий опирания и нагружения, идентичных натурному эксперименту, использована пара контактных элементов. Дополнительно применение контактных элементов позволило учесть трение между образцом и опорами.
\end{abstract}


The Comparative Analysis of the Results of Real and Numerical Experiments for Defining the Ultimate Bearing Capacity of Light Gauge Steel Studs "Atlant”

Одним из недостатков натурного эксперимента является отсутствие замеров начальных геометрических несовершенств. Для их учета предлагается использовать вероятностный подход. Подход подразумевает под собой расчет нескольких моделей с различными по величине и форме распределениями начальных несовершенств. В расчетные модели вносились начальные геометрические несовершенства (местные и общие), имеющие стохастический характер. Параметры распределения были получены на основе обмера восьмидесяти восьми образцов сплошных С-образных профилей [8]. В результате сравнения установлена хорошая сходимость результатов в плане предельной несущей способности. Часть образцов показала схожие картины деформирования. Как и ожидалось, результаты натурного эксперимента попали внутрь мнимого коридора, созданного результатами компьютерного моделирования.

Ключевые слова: ЛСТК, профили марки «АТЛАНТ», ANSYS, начальные геометрические несовершенства, натурный эксперимент

\section{TEST FIXTURE}

According to the presented report [1], the tests were conducted on the test fixture, depicted in Figure 1. The test fixture consists of three supporting structures, tightly attached to the reinforced floor, between which the horizontally positioned sample can be found. Both of sample ends wereattached totrackswith selftapping screws with the diameter of $4.8 \mathrm{~mm}$. One of the tracks ("the lower" one) was attached to the supporting structure along the full length with six bolts M12. Another track ("the upper" one) was fixed in its ends on the two remaining supporting structures, positioned at a distance of $L_{b r}=1219 \mathrm{~mm}$ with four bolts $\mathrm{M}$ 12. While testing both sample flanges, positioned in the center of the span, were constrained by using bands sized $38.1 \times 1.27$ $\mathrm{mm}$. The band length was $L_{s}=1219 \mathrm{~mm}$. Moreover, vertical mobility measurement at the $\mathrm{Y}$-axis was taken in the center of the span.

Sample adjustment on the test fixture was held by means of a laser pointer, positioned near "the lower" track. The load was transferred over the length (Z-axis) through "the upper" track with the help of servo-hydraulic actuator, equipped with the dynamometer. The mechanical motion transducer was installed in combination with the dynamometer at the Z-axis. The metal plate was assembled between the actuator and the track. The load was transferred continually with continuous traversing speed monitoring 0.76 $\mathrm{mm} / \mathrm{min}$.

\section{TESTS SAMPLES}

Three samples of steel studs "ATLANT" of two typical sizes were tested in the course of the experiment [2]. The first typical size (samples S1-S3): web height $H=152.4 \mathrm{~mm}$, flanges width $B=41.3 \mathrm{~mm}$, steel thickness $T k=$ $2.0 \mathrm{~mm}$. The second typical size (samples S4S6): web height $H=152.4 \mathrm{~mm}$, flanges width $B=41.3 \mathrm{~mm}$, steel thickness $T k=1.0 \mathrm{~mm}$. All six samples were of the length $L=$ 2438 мм. Before the experiment the measurements of the main geometrical parameters were made on each sample in three positions (beginning, middle, end). The results of the measurements are presented in Table 1.

According to [5], microscopic analysis of the metallographic specimen of each sample was conducted. The thickness of zinc covering as well as of base metal were defined. As the result of the experiment, there were graphs, made for each sample which describe the correlation between pressure load and sensor reading of the two motion detecting transducers. These graphs will be presented along with the results of computer modeling.

\section{COMPUTER MODELLING}

In order to display the results of the full-scale experiment by means of the ANSYS software [6] we created a series of CAE-models (Figure 2). 


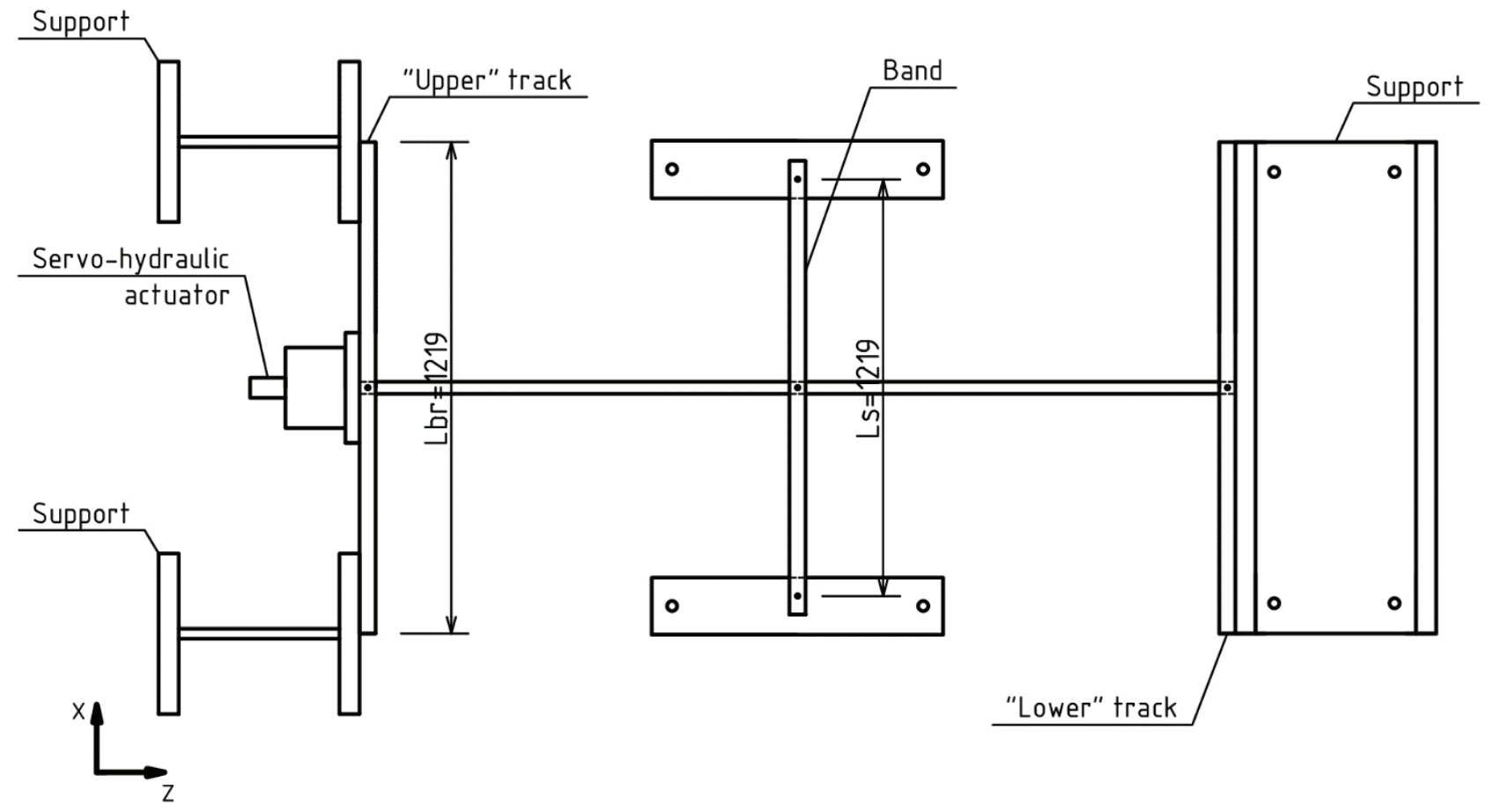

a)

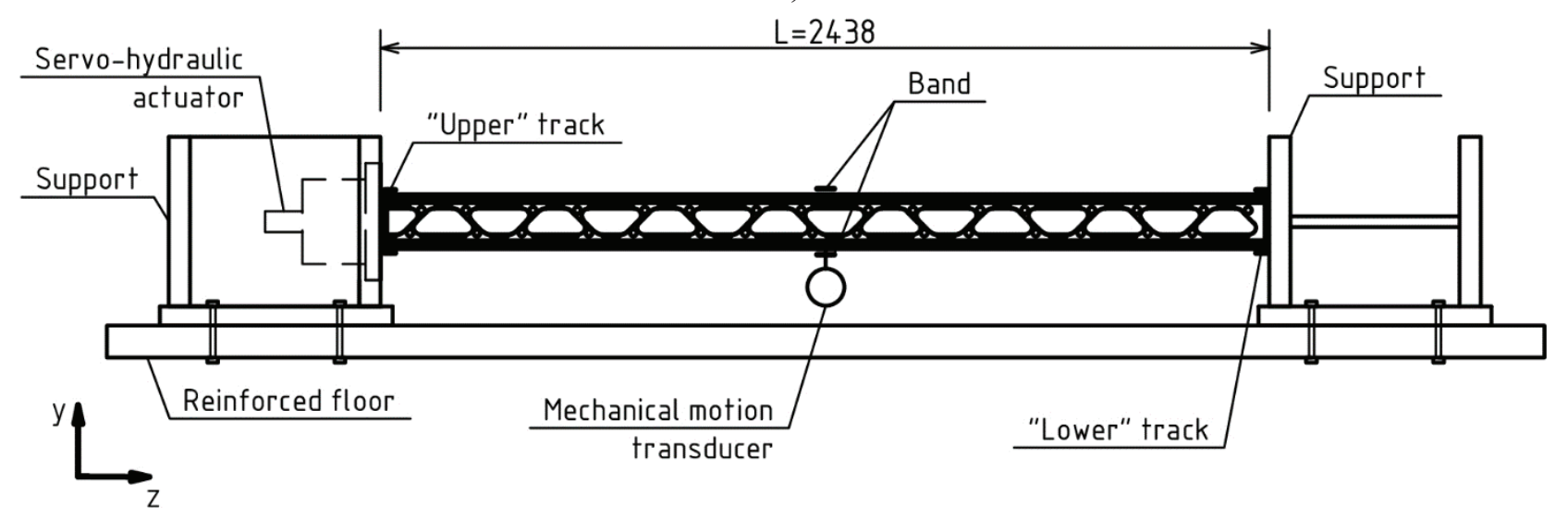

b)

Figure1. Testing bed scheme: a) top view; b) side-view.

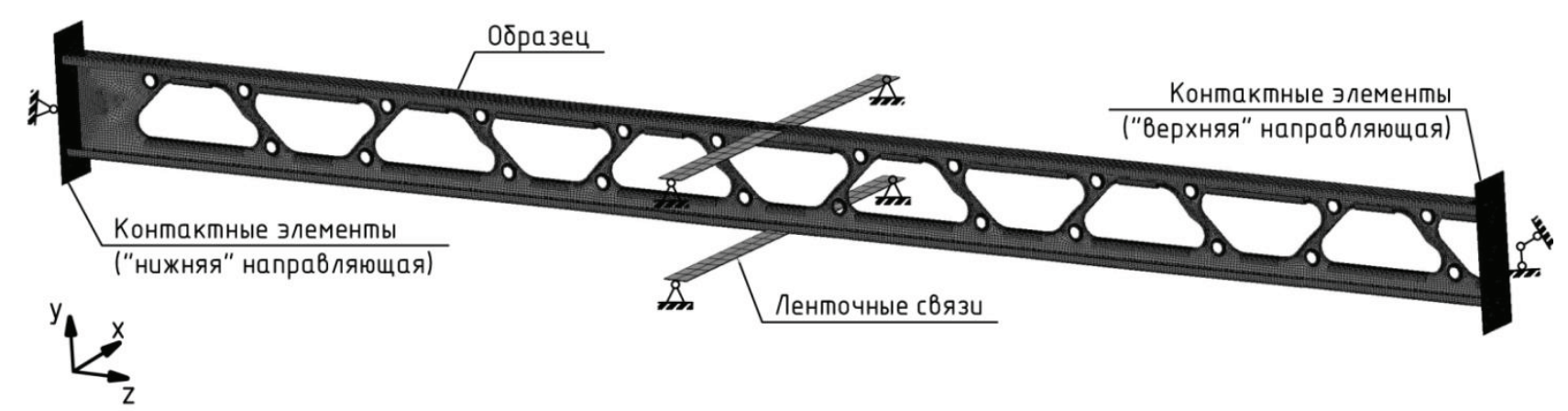

Figure 2. The overview of the calculating model. 
The Comparative Analysis of the Results of Real and Numerical Experiments for Defining the Ultimate Bearing Capacity of Light Gauge Steel Studs "Atlant”

Table 1. Geometrical parameters of steel studs.

\begin{tabular}{|c|c|c|c|c|c|c|}
\hline \multirow{2}{*}{ Parameter } & \multicolumn{3}{|c|}{ Sample S1 } & \multicolumn{3}{|c|}{ Sample S2 } \\
\hline & Beginning & Middle & End & Beginning & Middle & End \\
\hline$H, \mathrm{~mm}$ & 152.654 & 152.883 & 152.806 & 153.162 & 152.806 & 152.857 \\
\hline$B 1, \mathrm{~mm}$ & 41.720 & 41.605 & 42.012 & 41.250 & 42.520 & 42.113 \\
\hline$B 2, \mathrm{~mm}$ & 41.224 & 41.948 & 42.139 & 41.783 & 41.694 & 41.948 \\
\hline$C 1, \mathrm{~mm}$ & 12.891 & 12.751 & 14.402 & 12.459 & 12.586 & 11.938 \\
\hline$C 2, \mathrm{~mm}$ & 12.370 & 12.802 & 12.065 & 13.170 & 12.192 & 13.475 \\
\hline \multirow{2}{*}{ Parameter } & \multicolumn{3}{|c|}{ Sample S3 } & \multicolumn{3}{|c|}{ Sample S4 } \\
\hline & Beginning & Middle & End & Beginning & Middle & End \\
\hline$H, \mathrm{~mm}$ & 153.886 & 154.115 & 153.988 & 153.695 & 152.578 & 152.159 \\
\hline$B 1, \mathrm{~mm}$ & 41.123 & 41.021 & 41.326 & 41.554 & 41.059 & 42.824 \\
\hline$B 2, \mathrm{~mm}$ & 41.250 & 41.504 & 41.478 & 41.720 & 42.431 & 41.935 \\
\hline$C 1, \mathrm{~mm}$ & 13.284 & 13.030 & 14.669 & 12.852 & 12.560 & 13.551 \\
\hline$C 2, \mathrm{~mm}$ & 13.551 & 13.716 & 13.216 & 13.145 & 13.551 & 12.789 \\
\hline \multirow{2}{*}{ Parameter } & \multicolumn{3}{|c|}{ Sample S5 } & \multicolumn{3}{|c|}{ Sample S6 } \\
\hline & Beginning & Middle & End & Beginning & Middle & End \\
\hline$H, \mathrm{~mm}$ & 153.822 & 152.705 & 152.171 & 153.899 & 152.603 & 152.438 \\
\hline$B 1, \mathrm{~mm}$ & 42.050 & 41.021 & 42.901 & 42.164 & 41.072 & 42.824 \\
\hline$B 2, \mathrm{~mm}$ & 42.139 & 42.215 & 41.745 & 42.050 & 41.999 & 41.707 \\
\hline$C 1, \mathrm{~mm}$ & 12.624 & 12.306 & 12.687 & 12.751 & 12.306 & 13.360 \\
\hline$C 2, \mathrm{~mm}$ & 12.852 & 13.526 & 12.751 & 13.157 & 13.500 & 12.954 \\
\hline
\end{tabular}

The model consists of the test sample, bands and rigid supports. Shell members SHELL181 with the average size of 3-5 $\mathrm{mm}$ were used for creating the final-element mesh. Beam elements BEAM188 were used for creating bands. For modeling the band attachment in the sample flanges we prepared holes with the diameter of $4.8 \mathrm{~mm}$ which is equal to the self-tapping screws diameter. Nodes along the circuit holes joined in the rigid region with "the master" node, positioned in the center of the hole. The attachment of beam elements of bands was done by combination of displacements ( $u x, u y, u z)$ with the correspondent nodes and the "the master" node. For the purpose of supporting condition and load modeling which are identical to the full-scale experiment, we used a pair of contact elements CONTA177 (end of the sample) and TARGE170 (face of support plate). Given that stiffness of rigid supporters transferring the load is considerably greater than the stiffness of the sample, the elements TARGE170 were used in nondeformable formulation and were guided by "the master" nodes.

In addition, the use of contact elements allowed us to consider friction between the sample and the supporting structures (frictional coefficient $\mu=0.25$ ). The load modeling was conducted by moving the contact elements TARGE170 of 
"the upper" track at the Z-axis toward "the lower" track. The following boundary conditions were put: "the master" node of the contact elements of "the lower" track and the side nodes of the bands were constrained in $u x$, $u y, u z$; "the master" node of the contact elements of "the upper" track - $u x, u y$. For accounting steel material nonlinearity we used a multilinear model with isotropic hardening (MISO) [7]. The proper diagram was used for each typical size in accordance with the experiments on the tensile-testing machine.

One of the disadvantages of the full-scale experiment isthe absence of measurements of the initial geometrical imperfections. For their consideration the use of probabilistic approach is suggested. This approach entails calculation of several models with different spread of initial imperfections. The value of imperfections was obtained on the basis of normal distribution [8], derived from the measurement of $88 \mathrm{~m}$ solid Cshaped studs. It is anticipated that distribution of initial imperfections of real samples is in the diapason of computer modeling. Therefore, the results of the full-scale experiments are supposed to be inside the fictitious "corridor", created in accordance with the results of computer modeling.

Implementation of the initial geometrical imperfections with stochastic nature was done in the following order. Firstly, the initial local and general buckling modes were defined on the basis of the linear buckling analyses (Figure 3 ). Figure 4 a presents $u y$ flange displacement in the line 1-2 (Figure 3 ) in case of local buckling. It is clear that the shape in question is wavy with a variable half-wave length. With the purpose to give this shape stochastic nature it was decided to set up the peak amplitude for each separate section (highlighted by a dashed line) between zero displacement $u y$. The peak amplitude was deduced by normal distribution. The parameters of normal distribution for this type of imperfection are applied to thickness of steel $D / T k$ and described in paper [8]: mean value $\mu=0.26$, standard deviation $\sigma=0.49$.On the basis of this distribution 5 variants of the peak magnitude amplitude were defined for each section. Therefore, we prepared 5 calculating models for each typical size of the stud which are different in their shape and the value of initial geometrical imperfections. The variants ANS1-x relate to the first typical size of the stud with the metal thickness of $2.0 \mathrm{~mm}$; variants ANS2-x relate to the second typical size of the stud with the metal thickness of 1.0 $\mathrm{mm}$. The symbol " $\mathrm{x}$ " stands for the variant number of imperfections introduction. The result of amplitude adjustment with the consideration of stochastic nature is presented in Figure 4b.

General initial imperfections were introduced according to the related buckling mode which is a curve along the sinusoidal wave in a plane of lesser stiffness. For each of the 10 variants on the basis of normal distribution [8] $(\mu=2033$, $\sigma=3471$ ) we generated a series of values $(L / 2) / \Delta$, where $\Delta$ is an imperfection value. In addition to 10 variants described, four models were prepared. Initial imperfections were absolutely absent in variants ANS1-6, ANS2-6. The value of initial imperfections was raised to the level of standard values in variants ANS1-7, ANS2-7. In order to instill the model with stochastic nature, geometrical sizes of the calculating models were also computed on the basis of normal distribution.

\section{COMPARATIVE ANALYSIS}

According to the results of full-scale experiments and computer modeling, we obtained correlations between the value of pressure load and: a) displacement $u z$ of the sample end in the position of "the upper" track; b) displacement $u y$ of "the lower" stud flange inthe centre of the span. The correlation of pressure load and displacement $u z$ is presented in Figure 5 for pictorial comparison. The value of ultimate compressive force corresponding to full-scale experiments occurred in the interval, obtained by computer modeling.

The diapason of the results of the first type of 
The Comparative Analysis of the Results of Real and Numerical Experiments for Defining the Ultimate Bearing Capacity of Light Gauge Steel Studs "Atlant”

the typical size (ANS1-x) was from $67.8 \mathrm{kN}$ to $92.1 \mathrm{kN}$. The results of full-scale experiments are presented homogeneously inside the interval, which indicates that the value of initial geometrical imperfections in real samples (S1-S3) varied from minimum to maximumallowable. The diapason of the results of the second type of the typical size (ANS2-x) was from $24.5 \mathrm{kN}$ to $34.6 \mathrm{kN}$. Furthermore, the results of full-scale experiments (S4-S6) are presented close to the lower limit, which confirms the fact that the value of initial imperfections of the samples was close to the limit value.

According to the results of full-scale experiment $u_{z}$ and $u_{y}$ correspond to the ultimate bearing stress and on average 2-4 times exceed similar meanings, derived by computer modeling. Nevertheless, the difference in the absolute values does not exceed $9 \mathrm{~mm}$ for the samples of the first typical size, $3.4 \mathrm{~mm}$ - for the samples of the second typical size.

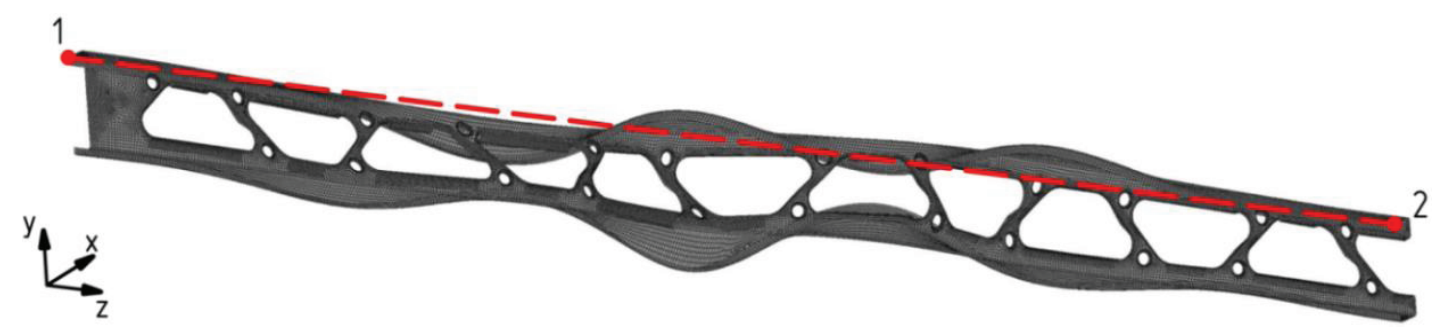

Figure 3. First local buckling mode.

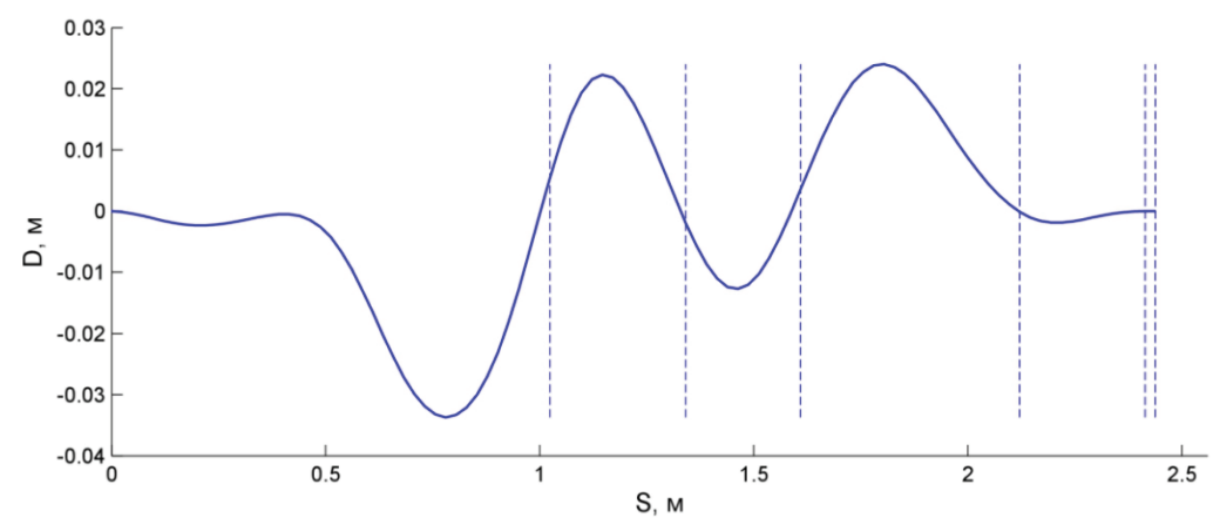

a)

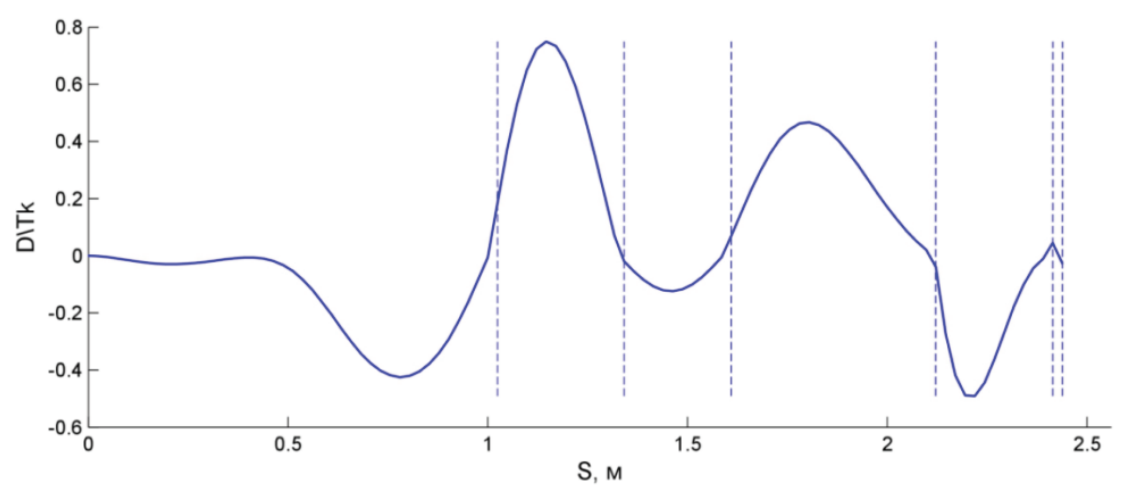

b)

Figure 4. Displacement uy along the line 1-2: a) in original shape;

b) in adjusted shape with consideration of stochastic nature. 
The results of computer modeling demonstrate patterns of deformation which are similar to full-scale experiments. Sample S1 pattern corresponds to the results of computer modeling of the variant ANS1-4 (Figure 6) - in both cases we can observe a considerable curve of the upper flange in the centre of the second half of the stud. Sample S3 pattern corresponds to the results of computer modeling of the variant ANS1-5 - in both cases we can observe a considerable curve of the upper flange in the centre of the first half of the stud.

The ultimate bearing stress values were close: the measure of inaccuracy between the results S1 and ANS1-4 - 4.3\%, between the results S3 and ANS $1-5-0.74 \%$.

The identical pattern of deformation is observed in samples S4-S6- a local curve of the upper flange on the first half of the stud.

The similar pattern of deformation is observed in sample ANS2-5.

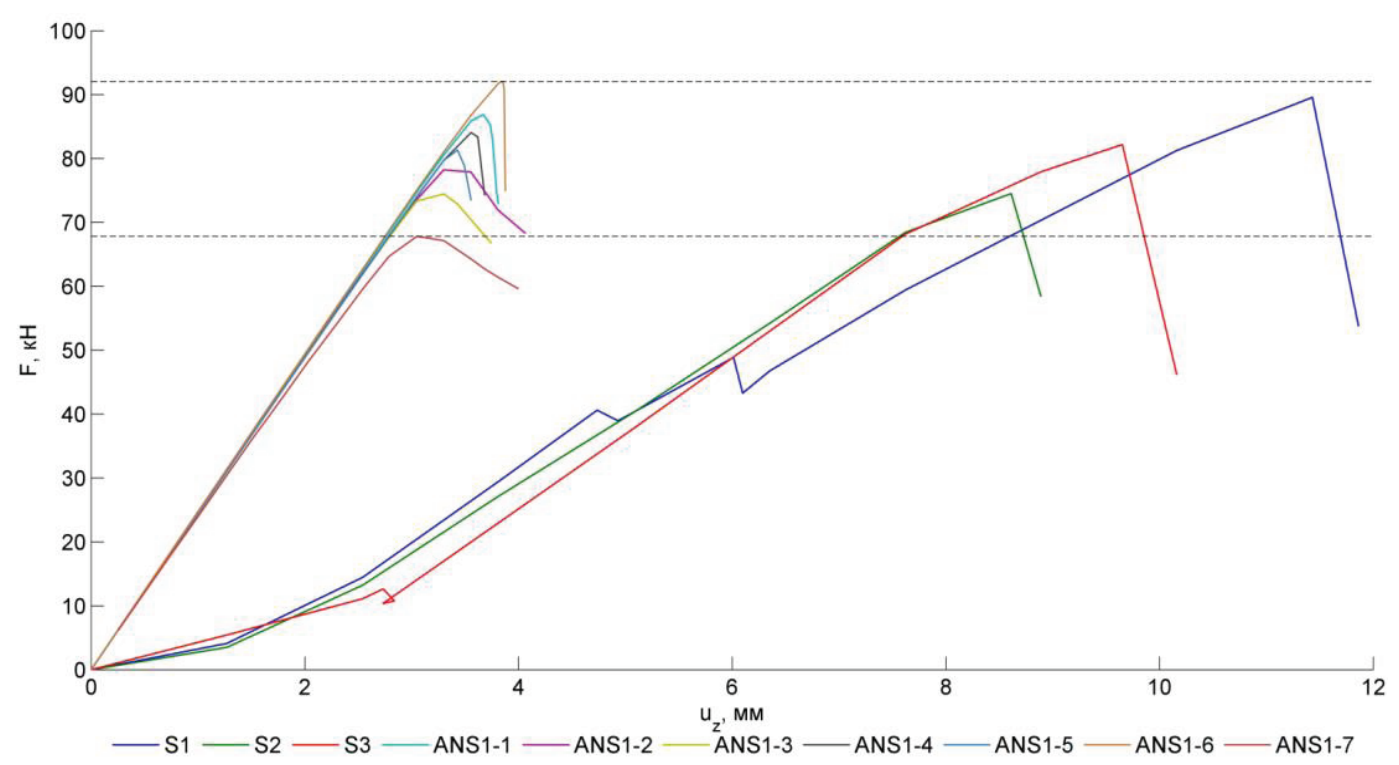

a)

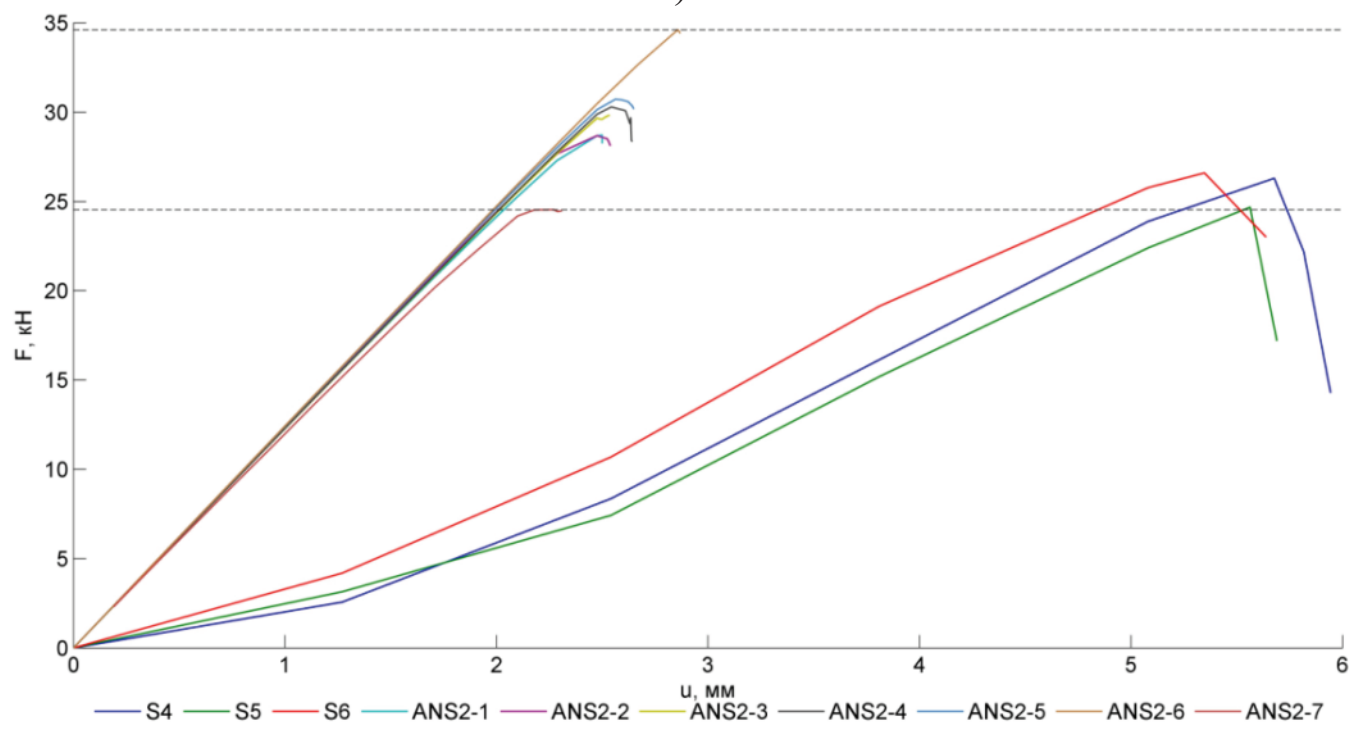

b)

Figure 5. Correlation between compressive force and displacement uz for samples:

a) first typical size; b) second typical size. 


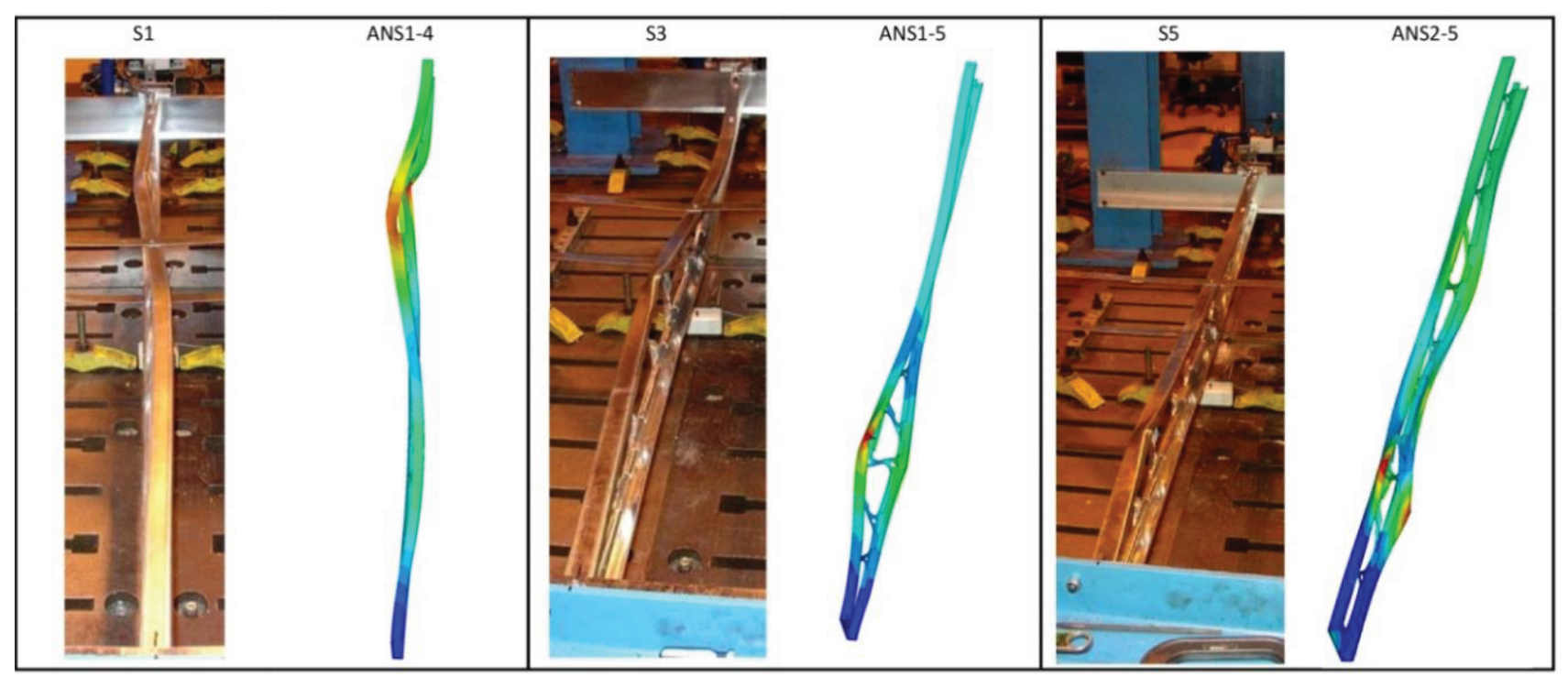

Figure 6. Deformation comparison.

\section{REFERENCE}

1. 06-03-C002. Compression test on single joist sample. Bodycote materials testing Canada, 2006, 5 pages.

2. TU 1120-001-43048595-2015 Profili holodnognutye "Atlant", 2015, 25 pages.

3. ASTM A370 - 17a. Standard Test Methods and Definitions for Mechanical Testing of Steel Products. ASTM International, 2017.

4. Aleksandrov A.V., Potapov V.D., Derzhavin B.P. Soprotivlenie Materialov [Strength of Materials]. Moscow, Vysshaya Shkola, 2003, 560 pages.

5. ASTM B487 Standard Test Method for Measurement of Metal and Oxide Coating Thickness by Microscopical Examination of Cross Section. ASTM International, 2013.

6. Ansys Inc. ANSYS Mechanical APDL Structural Guide. Edition 15, 2013.

7. Basov K.A. ANSYS: Spravochnik Pol'zovatelia [ANSYS: User's guide]. Moscow, DMK Press, 2005, 640 pages.

8. Vahid Zeinoddini-Meimand. Geometric imperfections in cold-formed steel members. The Johns Hopkins University, 2011.

\section{СПИСОК ЛИТЕРАТУРЫ}

1. 06-03-C002 Compression test on single joist sample. Bodycote materials testing Canada, 2006, 5 pages.

2. ТУ 1120-001-43048595-2015 Профили холодногнутые «Атлант», 2015. - 25 с.

3. ASTM A370 - 17a Standard Test Methods and Definitions for Mechanical Testing of Steel Products. ASTM International, 2017.

4. Александров А.В., Потапов В.Д., Державин Б.П. Сопротивление материалов. - М.: Высшая школа, 2003. $-560 \mathrm{c}$.

5. ASTM B487 Standard Test Method for Measurement of Metal and Oxide Coating Thickness by Microscopical Examination of Cross Section. ASTM International, 2013.

6. Ansys Inc. ANSYS Mechanical APDL Structural Guide. Edition 15, 2013.

7. Басов К.А. ANSYS: Справочник пользователя. - М.: ДМК Пресс, 2005. $640 \mathrm{c}$.

8. Vahid Zeinoddini-Meimand. Geometric imperfections in cold-formed steel members. The Johns Hopkins University, 2011. 
Galina G. Kashevarova, Corresponding Member of Russian Academy of Architecture and Construction Sciences, Professor, Dr.Sc., Head of department "Building constructions and computational mechanics", Perm National Research Polytechnic University; Russia, 614010, Perm, ul. Kuibyshev, 109; phone +7 (342) 219-83-61, e-mail: ggkash@mail.ru.

Pavel A. Kosykh, Engineer, Perm National Research Polytechnic University; 109, Kujbysheva street, Perm, 614010, Russia; phone +7 (342) 219-83-61, E-mail: paolo_07@list.ru.

Кашеварова Галина Геннадьевна, член-корреспондент РААСН, доктор технических наук, профессор, заведующая кафедрой «Строительные конструкции и вычислительная механика» Пермского национального исследовательского политехнического университета; 614010, Россия, г. Пермь, ул. Куйбышева, 109; тел. +7(342) 219-83-61, e-mail: ggkash@mail.ru.

Косых Павел Андреевич, инженер, Пермский национальный исследовательский политехнический университет; 614010, Россия, г. Пермь, ул. Куйбышева, 109; тел. +7 (342) 219-83-61;

E-mail: paolo_07@list.ru. 